\title{
Investasi dalam Perspektif Ekonomi Islam: Pendekatan Teoritis dan Empiris
}

\author{
Elif Pardiansyah \\ Universitas Indonesia Jakarta \\ email: elfardianzyah@gmail.com
}

\begin{abstract}
Investment is a commitment to withhold excess funds in order to gain profit in the future. Nevertheless, there are unscrupulous individuals who utilize investment as a means of collecting funds from the public with products and activities that are not according to sharia. Therefore, explaining the principles of sharia in investing becomes important as a guide for society. Eclpisit and implicit investment activities contained in the number of Qur'anic verses and the sunnah of the Prophet Muhammad, who once ran the business and became a partner of the Mecca investor of his day. The principle of sharia investment is any form of muamalah may be done until there is a prohibited prohibition, the water search for forbidden activities in a business activity, both object (product) and the process of activity that contains elements haram, gharār, maysīr, ribā, tadliss, talaqqī al-rukbān, ghabn, darar, rishwah, maksiat and zulm. In investing, there are sharia rules regarding what covenants are allowed, what is prohibited, and risks that arise as an integral part of investment activity.
\end{abstract}

Keywords: investment; sharia principles of investment; speculation; sharia financial risk.

Abstrak: Investasi merupakan komitmen untuk menahan sejumlah dana dengan tujuan memperoleh sejumlah keuntungan di masa yang akan datang. Namun demikian, terdapat oknum yang memanfaatkan investasi sebagai alat menghimpun dana dari masyarakat dengan produk dan aktifitas usaha yang tidak sesuai syariah. Oleh sebab itu, penjelasan prinsip-prinsip syariah dalam berinvestasi menjadi penting sebagai panduan bagi masyarakat. Kegiatan investasi secara eklpisit maupun implisit tertuang di dalam sejumlah ayat AlQur'an dan sunnah nabi Muhammad saw. yang pernah menjalankan bisnis dan menjadi mitra investor Mekah pada masanya. Prinsip investasi syariah adalah semua bentuk muamalah boleh dilakukan sampai ada dalil yang melarangnya, yaitu apabila ditemukan kegiatan terlarang dalam suatu kegiatan bisnis, baik objek (produk) maupun proses kegitan usahanya yang mengandung unsur haram, gharār, maysīr, ribā, tadlīs, talaqqī al-rukbān, ghabn, ḍarar, rishwah, maksiat and zulm. Dalam investasi, terdapat aturan syariah mengenai akad apa saja yang dibolehkan, apa yang dilarang, dan risiko yang timbul sebagai bagian integral dari kegiatan investasi

Kata Kunci: investasi; prinsip syariah investasi; spekulasi; risiko investasi syariah. 


\section{Pendahuluan}

Dewasa ini, kita mengenal investasi "bodong” yang dilakukan oleh orang atau entitas tertentu. Investasi "bodong" bermunculan dari waktu ke waktu dengan berbagai macam modus. Modusnya, ada yang setor investasi 1 juta rupiah dengan janji akan mendapatkan bonus 5\% setiap bulan dan mendapatkan bonus 10\% jika mendapat anggota baru. Ada juga dengan modus investasi 100 juta rupiah selama 12 bulan dan tidak bisa diambil, dengan janji mendapat keuntungan 30\% per bulan; bahkan investasi bulan ke-1 sebesar 1 juta dan bulan ke-2 sampai bulan ke-3 mendapatkan cash back 1 juta setiap bulan.

Lebih jauh lagi, Satgas Waspada Investasi yang dibentuk Otoritas Jasa Keuangan (OJK) mencatat pada tahun 2015 terdapat 200 modus investasi bodong (tidak berizin) dan rawan penipuan. Sedangkan pada tahun 2016 terdapat lebih dari 400 modus investasi serupa. Tidak hanya itu, 90\% dari modus investasi tersebut tidak memiliki izin, sedangkan $10 \%$ sisanya hanya memiliki izin SIUP dan TDP, namun tidak memiliki izin investasi. Satgas Waspada Investasi memberikan panduan kepada masyarakat calon investor untuk mewaspasai beberapa ciri investasi bodong diantaranya: high return, free risk, high insentive, unfair, big promise dan guarantee.

Data yang dirilis oleh Satgas Waspada Investasi OJK pada pertengahan bulan Desember 2017 adalah terdapat 21 entitas yang diduga melakukan praktek bisnis dan investasi yang mencurigakan dengan janji return yang sangat tinggi. Temuan tersebut menunjukkan bahwa praktik kotor dalam bisnis dan investasi hidup dan mengancam masyarakat. Tentu masyarakat yang tidak melek investasi dan prinsip berinvestasi yang aman akan banyak yang tertipu oleh iming-iming return yang begitu tinggi.

Investasi merupakan kegiatan yang dianjurkan dalam pandangan Islam. Hal ini karena kegiatan investasi sudah dilakukan oleh nabi Muhammad saw. sejak muda sampai menjelang masa kerasulan. Selain itu akan tercapainya 
Investasi dalam Perspektif Ekonomi Islam...

maslahah multiplayer effect, di antaranya tercipta lapangan usaha dan lapangan pekerjaan, menghindari dana mengendap dan agar dana tersebut tidak berputar di antara orang kaya saja (QS. al-Hasyr [59]: 7). Lebih dari itu, investasi mendapat legitimasi langsung di dalam Al-Qur'an dan Sunnah Nabi saw. Banyak ayat Al-Qur'an yang terkait dengan anjuran berinvestasi, seperti QS. al-Baqarah [2]: 261; QS. al-Nisa [4]: 9; QS. Yusuf [12]: 46-49; QS. Luqman [31]: 34 dan QS. al-Hasyr [59]: 18. Sunnah Nabi saw. yang berkaitan dengan bisnis adalah segala perkataan, perbuatan atau ketetapan nabi saw. dalam menjalankan aktifitas bisnisnya. Dalam catatan sejarah, Nabi saw. pernah mengelola modal milik janda kaya Mekkah dan harta waris anak yatim, dan beberapa hadis perkataan nabi saw. yang mengakui perserikatan (penyertaan modal) di dalam aktivitas bisnis.

Investasi merupakan bagian dari fikih muamalah, maka berlaku kaidah "hukum asal dalam semua bentuk muamalah adalah boleh dilakukan kecuali ada dalil yang mengharamkannya" (Djazuli. A 2006). Aturan ini dibuat karena ajaran Islam menjaga hak semua pihak dan menghindari saling menzalimi satu sama lain. Hal ini menuntut para investor untuk mengetahui batasanbatasan dan aturan investasi dalam Islam, baik dari sisi proses, tujuan, dan objek dan dampak investasinya. Namun demikian, tidak semua jenis investasi diperbolehkan syariah seperti kasus bisnis yang diungkapkan di atas yaitu mengandung penipuan dan kebohongan atau mengandung unsur-unsur kegiatan yang dilarang syariat Islam.

Kasus-kasus seperti yang disinggung di atas, tetap saja marak dilakukan oleh oknum perorangan, koperasi, atau entitas tertentu demi mendapat keuntungan yang besar tanpa memedulikan norma-norma yang berlaku, baik norma positif dan maupun norma agama. Realita ini tentu sangat mengkhawatirkan di saat tren kondisi perekonomian sedang melemah, ditambah dengan kenyataan semakin banyaknya entitas yang mengatasnamakan investasi, namun kenyataanya penipuan masih marak. Di sinilah Islam hadir dengan membawa ajaran rahmatan li al-'ālamīn (rahmat 
bagi seluruh alam) dengan memberikan panduan prinsip syariah dalam berinvestasi agar tidak terjerumus ke dalam bisnis yang dilarang. Dalam tulisan ini akan diuraikan mengenai hubungan investasi dan Islam, dasar hukum investasi dalam Al-Qur'an dan Sunnah Nabi saw., prinsip syariah dalam berinvestasi, asas fikih muamalah, kegiatan yang dilarang dalam berinvestasi dan akad-akad yang digunakan dalam kegiatan investasi, agar semua pihak yang berkepentingan dalam kegiatan ini dapat membedakan dan memilih investasi mana yang boleh, halal dan baik.

\section{Definisi dan Ruang Lingkup Investasi}

Investasi berasal dari bahasa Inggris investment dari kata dasar invest yang berarti menanam, atau istathmara dalam bahasa Arab, yang berarti menjadikan berbuah, berkembang dan bertambah jumlahnya (Antonio 2007). Secara istilah, investasi adalah barang tidak bergerak atau barang milik perseorangan atau perusahaan yang dimiliki dengan harapan untuk mendapatkan pendapatan periodik atau keuntungan atas penjualan dan pada umumnya dikuasai untuk periode yang relatif panjang (Rahmawan 2005).

Definisi yang sama diungkapkan Kasmir dan Jakfar, dimana investasi dapat diartikan sebagai penanaman modal dalam suatu kegiatan yang memiliki jangka waktu relatif panjang dalam berbagai bidang usaha atau proyek yang membutuhkan dana dengan tujuan memperoleh keuntungan (Kasmir dan Jakfar 2015); (Arifin 2009). Investasi menurut Islam adalah penanaman dana atau penyertaan modal untuk suatu bidang usaha tertentu yang kegiatan usahanya tidak bertentangan dengan prinsip-prinsip syariah, baik objeknya maupun prosesnya.

Dalam perhitungan pendapatan nasional, pengertian investasi adalah pengeluaran untuk membeli barang-barang modal dan peralatan-peralatan produksi dengan tujuan untuk mengganti dan terutama menambah barangbarang modal dalam perekonomian yang akan digunakan untuk memproduksi barang-barang dan jasa di masa depan (Maharani 2016). 
Investasi dalam Perspektif Ekonomi Islam...

Tujuan pengeluaran untuk investasi adalah pembelian barang-barang yang memberi harapan menghasilkan keutungan yang akan datang. Artinya, pertimbangan yang diambil oleh pengusaha atau perusahaan dalam memutuskan membeli atau tidak membeli barang dan jasa tersebut adalah harapan dari pengusaha atau perusahaan akan kemungkinan keuntungan yang dapat diperoleh. Harapan keuntungan ini merupakan faktor utama dalam investasi (Sitompul 2007).

Menurut Sukirno (Sukirno 2003), kegiatan investasi memungkinkan suatu masyarakat terus menerus meningkatkan kegiatan ekonomi dan kesempatan kerja, meningkatkan pendapatan nasional dan meningkatkan taraf kemakmuran masyarakat. Peranan ini bersumber dari tiga fungsi penting dari kegiatan investasi, yakni: (1) investasi merupakan salah satu komponen dari pengeluaran agregat, sehingga kenaikan investasi akan meningkatkan permintaan agregat, pendapatan nasional serta kesempatan kerja; (2) pertambahan barang modal sebagai akibat investasi akan menambah kapasitas produksi; (3) investasi selalu diikuti oleh perkembangan teknologi. Pendapat serupa dikemukakan Nopirin (Nopirin 2000), untuk terjadinya pertumbuhan ekonomi, diperlukan peningkatan produksi nasional. Peningkatan produksi nasional dapat terjadi karena adanya akumulasi modal yang diperoleh dari tabungan nasional yang nantinya akan digunakan untuk melakukan investasi.

Kegiatan investasi sebagaimana dijelaskan di atas, memiliki manfaat dan dampak yang luas bagi perekonomian suatu negara. Namun demikian, secara prinsip, Islam memberikan panduan dan batasan yang jelas mengenai sektor mana saja yang boleh dan tidak boleh dimasuki investasi. Tidak semua investasi yang diakui hukum positif, diakui pula oleh syariat Islam. Oleh sebab itu, agar investasi tersebut tidak bertentangan, maka harus memperhatikan dan memperhitungkan berbagai aspek, sehingga hasil yang didapat sesuai dengan prinsip syariah. Berikut ini adalah beberapa aspek yang harus dimiliki dalam berinvestasi menurut perspektif Islam (Chair 2015):

Economica: Jurnal Ekonomi Islam - Volume 8, Nomor 2 (2017) http://journal.walisongo.ac.id/index.php/economica 
a. Aspek material atau finansial. Artinya suatu bentuk investasi hendaknya menghasilkan manfaat finansial yang kompetitif dibandingkan dengan bentuk investasi lainnya.

b. Aspek kehalalan. Artinya suatu bentuk investasi harus terhindar dari bidang maupun prosedur yang subhat atau haram. Suatu bentuk investasi yang tidak halal hanya akan membawa pelakunya kepada kesesatan serta sikap dan perilaku destruktif (darūrah) secara individu maupun sosial.

c. Aspek sosial dan lingkungan. Artinya suatu bentuk investasi hendaknya memberikan kontribusi positif bagi masyarakat banyak dan lingkungan sekitar, baik untuk generasi saat ini maupun yang akan datang.

d. Aspek pengharapan kepada rida Allah. Artinya suatu bentuk investasi tertentu dipilih adalah dalam rangka mencapai rida Allah.

Investasi sejatinya terbagi menjadi dua, yaitu investasi langsung (direct investment) seperti berwirausaha/mengelola usaha sendiri pada sektor riil (riil sector) dan investasi tidak langsung (indirect investment) investasi pada sektor non-riil seperti investasi di perbankan syariah (deposito) dan pasar modal syariah melalui bursa saham syariah, reksadana syariah, sukuk, SBSN, dan lain-lain.

Untuk investasi jenis pertama diperlukan langkah yang cermat penuh perhitungan, keberanian mengambil risiko (risk taker), kehati-hatian dan sikap profesionalisme dalam mengelola suatu kegiatan usaha. Sedangkan investasi jenis kedua (sektor non-riil) risikonya tidak sebesar sektor rill, walau demikian tetap memerlukan perhitungan dan strategi yang matang agar terhindar dari kerugian yang besar. Berikut adalah gambaran keuntungan dan kemungkinan rugi investasi pada sektor rill dan non-riil. 
Investasi dalam Perspektif Ekonomi Islam...

Gambar 1. Perbandingan tingkat keuntungan dan risiko berinvestasi

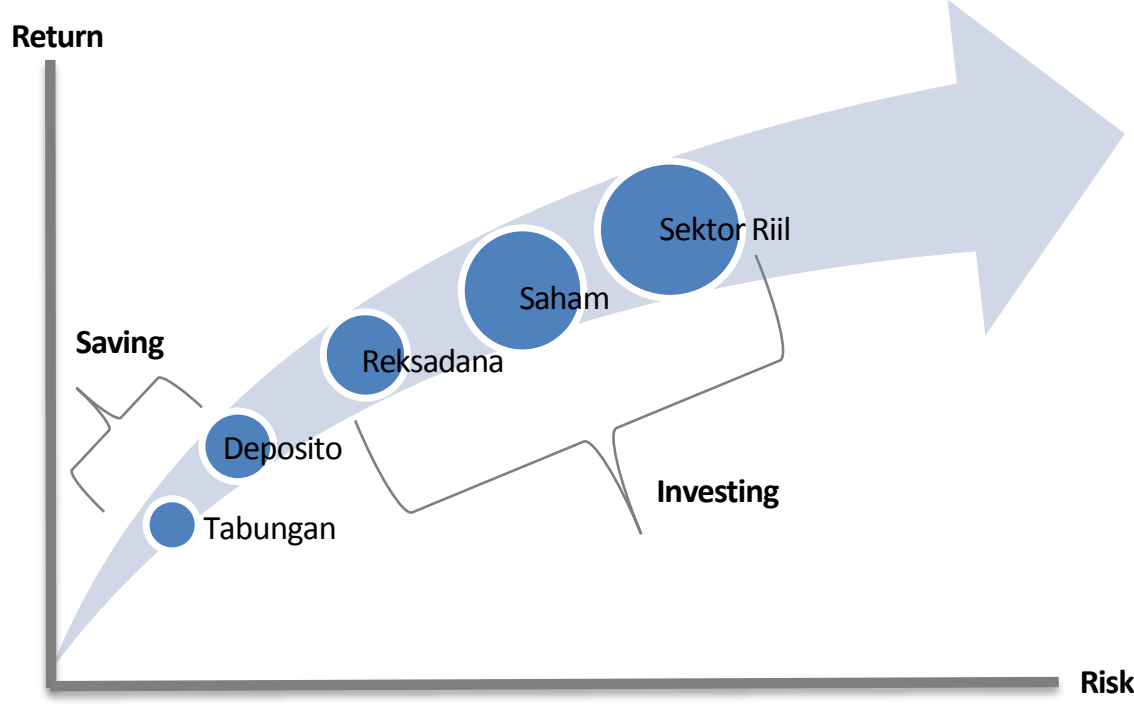

Sumber: Materi diolah dari TOT Pasar Modal Syariah OJK, 2017

Gambar 1. di atas sebagai gambaran perbandingan tingkat keuntungan (return) dan risiko (risk) dalam berinvestasi. Hal ini menunjukan, semakin tinggi keuntungan (return) dari investasi yang didapat maka akan berbanding lurus dengan risiko kerugian investasi. Begitupun sebaliknya, semakin rendah risiko ditanggung akan berbanding lurus dengan keuntungan didapat. Sektor rill bisa dikatakan sebagai lahan memperoleh keuntungan tinggi namun demikian risiko ruginya pun tinggi, sehingga tidak semua orang mampu bertahan dan mau terjun kepada jenis investasi sektor ini.

\section{Dasar Hukum Investasi dalam Islam}

Islam adalah agama yang pro-investasi, karena di dalam ajaran Islam sumber daya (harta) yang ada tidak hanya disimpan tetapi harus diproduktifkan, sehingga bias memberikan manfaat kepada umat (Hidayat 2011). Hal ini berdasarkan firman Allah swt.:

Economica: Jurnal Ekonomi Islam - Volume 8, Nomor 2 (2017) http://journal.walisongo.ac.id/index.php/economica 


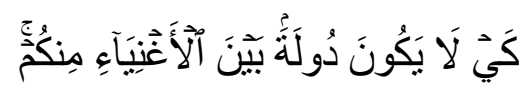

"supaya harta itu tidak beredar di antara orang-orang kaya saja di antara kalian”. (QS. al-Hasyr [59]: 7)

Oleh sebab itu dasar pijakan dari aktivitas ekonomi termasuk investasi adalah Al-Qur'an dan hadis Nabi saw. Selain itu, karena investasi merupakan bagian dari aktivitas ekonomi (muamalah māliyah), sehingga berlaku kaidah fikih, muamalah, yaitu "pada dasarnya semua bentuk muamalah termasuk di dalamnya aktivitas ekonomi adalah boleh dilakukan kecuali ada dalil yang mengharamkannya." (Fatwa DSN-MUI No. 07/DSN-MUI/IV/2000).

\section{Investasi Menurut Al-Qur'an}

a. QS. al-Baqarah [2]: 268

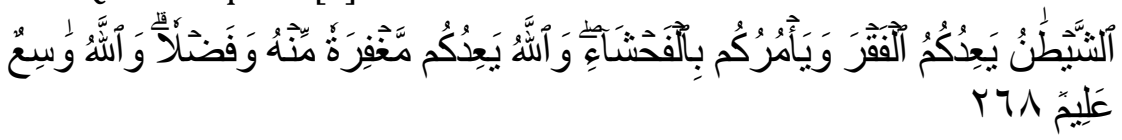

“Perumpamaan (nafkah yang dikeluarkan oleh) orang-orang yang menafkahkan hartanya di jalan Allah adalah serupa dengan sebutir benih yang menumbuhkan tujuh bulir, pada setiap bulir seratus biji. Allah melipat gandakan (ganjaran) bagi siapa yang Dia kehendaki dan Allah Maha Luas (karunia-Nya) lagi Maha mengetahui."

Ayat ini secara implisit memberikan informasi akan pentingnya berinvestasi, dimana ayat itu menyampaikan betapa beruntungnya orang yang menafkahkan hartanya di jalan Allah. Orang yang kaya secara financial (keuangan) kemudian menginfakkan hartanya untuk pemberdayaan masyarakat yang kurang mampu melalui usaha produktif, maka sesungguhnya dia sudah menolong ribuan, bahkan ratusan ribu orang miskin untuk berproduktif ke arah yang lebih baik lagi (Yuliana 2010).

b. QS. al-Nisa [4]: 9 


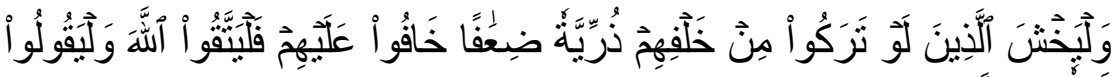

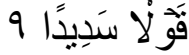

"Dan hendaklah takut kepada Allah orang-orang yang seandainya meninggalkan di belakang mereka keturunan yang lemah, yang mereka khawatir terhadap (kesejahteraan) mereka. Oleh sebab itu hendaklah mereka bertakwa kepada Allah dan hendaklah mereka mengucapkan perkataan yang benar."

Ayat ini dengan tegas memerintahkan kepada manusia untuk tidak meninggalkan keturunan dalam keadaan lemah, baik lemah moril maupun materil. Secara tersirat ayat ini memerintahkan kepada umat untuk meningkatkat kehidupan ekonomi melalui investasi jangka panjang. Investasi ini akan diwariskan kepada keturunannya untuk mencukupi kehidupan sampai ia layak berusaha sendiri/mandiri.

\section{c. QS. Yusuf [12]: 47-49}

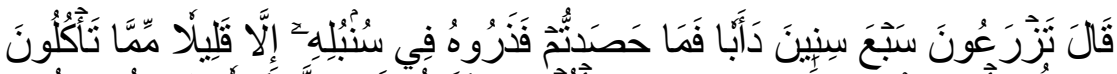
ع

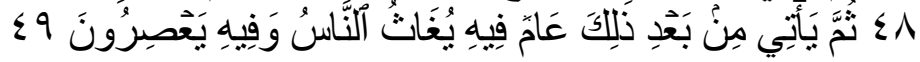

"Yusuf berkata: supaya kalian bertanam tujuh tahun (lamanya) sebagaimana biasa; maka apa yang kalian tuai hendaklah kalian biarkan di bulirnya kecuali sedikit untuk kalian makan. Kemudian sesudah itu akan datang tujuh tahun yang amat sulit, yang menghabiskan apa yang kalian simpan untuk menghadapinya (tahun sulit), kecuali sedikit dari (bibit gandum) yang kalian simpan. Kemudian setelah itu akan datang tahun yang padanya manusia diberi hujan (dengan cukup) dan di masa itu mereka memeras anggur."

Pelajaran (ibrah) dan hikmah dari ayat ini adalah bahwa manusia harus mampu menyimpan sebagian hartanya untuk mengantisipasi kejadian yang tidak terduga di kemudian hari. Atinya manusia hanya bisa berasumsi dan menduga yang akan terjadi hari esok, sedangkan secara pastinya hanya Allah yang Mahatahu. Oleh sebab itu, perintah nabi Yusuf as. dalam ayat di atas untuk menyimpan sebagian sebagai cadangan konsumsi di kemudian hari 
adalah hal yang baik. Begitu pun dengan menginvestasikan sebagian dari sisa konsumsi dan kebutuhan pokok lainnya akan menghasilkan manfaat yang jauh lebih luas dibandingkan hanya dengan disimpan (ditabung).

d. QS. al-Hasyr [59]: 18

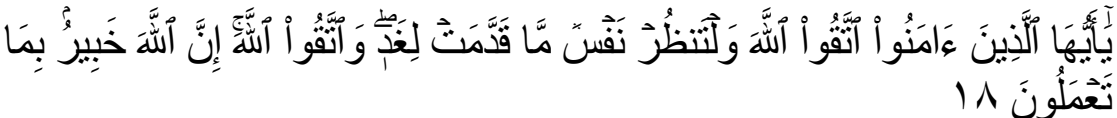

"Hai orang-orang yang beriman, bertakwalah kepada Allah dan hendaklah setiap diri memperhatikan apa yang telah diperbuatnya untuk hari esok (akhirat); dan bertakwalah kepada Allah, sesungguhnya Allah Maha mengetahui apa yang kalian kerjakan."

Ayat ini secara ekplisit memerintahkan manusia untuk selalu berinvestasi baik dalam bentuk ibadah maupun kegiatan muamalah māliyah untuk bekalnya di akhirat nanti. Investasi adalah bagian dari muamalah mäliyah, sehingga kegiatannya mengandung pahala dan bernilai ibadah bila diniatkan dan dilaksanakan sesuai dengan prinsip syariah.

e. QS. Luqman [31]: 34

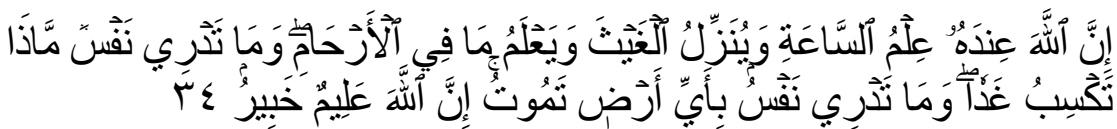

"Sesungguhnya Allah, hanya pada sisi-Nya sajalah pengetahuan tentang hari kiamat; dan Dia-lah yang menurunkan hujan, dan mengetahui apa yang ada dalam rahim. dan tidak ada seorang pun yang dapat mengetahui (dengan pasti) apa yang akan diusahakannya esok. Dan tidak seorang pun yang dapat mengetahui di bumi mana dia akan mati. Sesungguhnya Allah Maha mengetahui lagi Maha Mengenal."

Maksud dari ayat ini adalah, manusia itu tidak dapat mengetahui dengan pasti apa yang akan diusahakannya esok atau yang akan diperolehnya, namun demikian mereka diwajibkan berdoa, berikhtiar dan bertawakal. Salah satu ikhtiar manusia dalam mendayagunakan hartanya dengan cara berinvestasi sesuai prinsip syariah. 
Berdasarkan uraian ayat-ayat di atas, dapat diambil kesimpulan bahwa Islam memandang investasi sebagai hal yang sangat penting sebagai langkah atisipatif terhadap kejadian di masa depan. Seruan bagi orang-orang yang beriman untuk mempersiapkan diri (antisipasi) di hari esok mengindikasikan bahwa segala sesuatunya harus disiapkan dengan penuh perhitungan dan kecermatan. Dalam perspektif ekonomi, hari esok dalam ayat-ayat di atas bisa dimaknai sebagai masa depan (future).

\section{Investasi menurut Sunnah Nabi saw.}

Menurut catatan sejarah, saat masih kecil nabi Muhammad saw. pernah mengembala ternak penduduk Mekkah. Nabi saw. pernah berkata kepada para sahabatnya "semua nabi pernah menggembala". Para sahabat bertanya, "Bagaimana denganmu, wahai Rasulallah?" Beliau menjawab, "Allah swt tidak mengutus seorang nabi melainkan dia pernah menggembala ternak". Para sahabat kemudian bertanya lagi, "Engkau sendiri bagaimana wahai Rasulullah?" Beliau menjawab, "Aku dulu menggembala kambing penduduk Mekkah dengan upah beberapa qirāț" (Antonio 2007).

Profesi berdagang nabi saw. dimulai sejak beliau berusia 12 tahun, ketika ikut magang (internship) kepada pamannya untuk berdagang ke Syiria (Antonio 2007). Ketika muda, nabi saw. pernah juga mengelola perdagangan milik seseorang (investor) dengan mendapatkan upah dalam bentuk unta (Afzalurrahman 2000). Karir profesional nabi saw. dimulai sejak Muhammad muda dipercaya menerima modal dari para investor yaitu para janda kaya dan anak-anak yatim yang tidak sanggup mengelola sendiri harta mereka. Mereka menyambut baik seseorang untuk menjalankan bisnis dengan uang atau modal yang mereka miliki berdasarkan kerjasama muḍarabah (bagi hasil) (Antonio 2007).

Nabi Muhammad saw. dalam menjalankan bisnisnya senantiasa memperkaya dirinya dengan kejujuran, keteguhan memegang janji, dan sifatsifat mulia lainnya, sampai dijuluki sebagai orang yang terpercaya (al-amin). 
Para pemilik modal di Mekkah semakin banyak yang membuka peluang kemitraan dengan nabi saw. salah seorang pemilik modal tersebut adalah Khadijah yang menawarkan kemitraan berdasarkan muḍarabah (bagi hasil). Dalam hal ini, Khadijah bertindak sebagai șahib al-māl (pemilik modal) dan nabi Muhammad saw. sebagai mudarib (pengelola) (Antonio 2007). Bahkan sebelum menikah, beliau diangkat menjadi manajer perdagangan Khadijah ke pusat perdagangan Habashah di Yaman dan 4 kali memimpin ekspedisi perdagangan ke Syria dan Jorash di Yordania (Afzalurrahman 2000).

Dengan demikian, nabi Muhammad saw. memasuki dunia bisnis dan perdagangan dengan cara menjalankan modal orang lain (investor), baik dengan upah (fee based) maupun dengan sistem bagi hasil (profit sharing) (Antonio 2007). Profesi ini kurang lebih bertahan selama 25 tahun, angka ini sedikit lebih lama dari masa kerasulan Muhammad saw. yang berlangsung selama kurang lebih 23 tahun (Antonio 2007). Salah satu hadis beliau yang masyhur mengenai investasi dan perserikatan adalah:

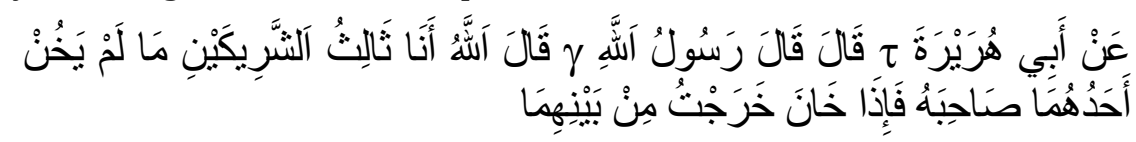

"Dari Abu Hurairah ra. bahwa Rasulullah saw. bersabda: Allah berfirman: Aku menjadi orang ketiga dari dua orang yang bersekutu selama salah seorang dari mereka tidak berkhianat kepada temannya. Jika ada yang berkhianat, aku keluar dari (persekutuan) mereka (HR. Abu Dawud dan dinilai shahih oleh al-Hakim).

Berdasarkan paparan di atas, praktik investasi sudah ada sejak nabi Muhammad saw., bahkan beliau secara langsung terjun dalam praktik binis dan investasi. Beliau memberikan contoh bagaimana mengelola investasi hingga mengasilkan keuntungan yang banyak. Hal ini tidak terlepas dari pengalaman beliau yang lama sebagai pedagang dan pengelola bisnis (muḍarib). Nabi saw. mempraktikkan bisnis dengan sangat profesional, tekun, ulet dan jujur serta tidak pernah ingkar janji kepada pemilik modalnya (investor). Kegiatan investasi juga dipraktikkan di jaman amirul mukminin, 
Investasi dalam Perspektif Ekonomi Islam...

Umar bin Khattab dimana ia pernah berkata, "Siapa saja yang memiliki uang, hendaklah ia menginvestasikannya dan siapa yang memiliki tanah hendaklah ia menanaminya (mengelolanya)" (Hidayat 2011). Oleh sebab itu, investasi dalam ajaran Islam tidak dilarang, bahkan dianjurkan supaya memberikan dampak dan manfaat yang luas dengan terciptanya lapangan pekerjaan dan lapangan usaha baru.

\section{Prinsip Syariah dalam Investasi}

Prinsip adalah elemen pokok yang menjadi struktur atau kelengkapan sesuatu (UII 2013), berbeda dengan asas yaitu landasan atau dasar tempat berpijaknya sesuatu dengan tegak (Langgulung 1992). Adapun prinsip syariah yang dimaksud dalam tulisan ini adalah prinsip hukum Islam dalam kegiatan ekonomi dan bisnis berdasarkan fatwa yang dikeluarkan oleh lembaga yang memiliki kewenangan dalam penetapan fatwa di bidang syariah. Lembaga fatwa yang dimaksud di sini adalah Dewan Syariah Nasional Majelis Ulama Indonesia (DSN-MUI).

Namun demikian perlu dijelaskan terlebih dahulu asas-asas fikih muamalah, karena kegiatan investasi merupakan bagian dari bermuamalah māliyah, dan asas merupakan pijakan berdirinya prinsip. Asas-asas fikih muamalah sebagaimana dikemukakan Ahmad Azhar Basyir (Basyir 2000), adalah sebagai berikut:

a. Pada dasarnya segala bentuk muamalah adalah mubah (boleh) kecuali ada dalil yang mengharamkannya (yang ditentukan lain oleh Al-Qur'an dan sunnah Rasul) (Djazuli. A 2006); Konsideran Fatwa DSN-MUI);

b. Muamalah dilakukan atas dasar sukarela tanpa mengandung unsur paksaan (Praja 2004);

c. Muamalah dilakukan atas dasar pertimbangan mendatangkan manfaat dan menghindari mudharat dalam hidup masyarakat (Sahroni 2016); 
d. Muamalah dilakukan dengan memelihara nilai keadilan, menghindari unsur-unsur penganiayaan, unsur-unsur darar (membahayakan), dan unsur-unsurpengambilan kesempatan dalam kesempitan.

Selain itu, ada beberapa prinsip syariah khusus terkait investasi yang harus menjadi pegangan bagi para investor dalam berinvestasi (Aziz 2010), yaitu:

a. Tidak mencari rezeki pada sektor usaha haram, baik dari segi zatnya (objeknya) maupun prosesnya (memperoleh, mengolah dan medistribusikan), serta tidak mempergunakan untuk hal-hal yang haram;

b. Tidak menzalimi dan tidak pula dizalimi (la tazlimūn wa lā tuẓlamūn);

c. Keadilan pendistribusian pendapatan;

d. Transaksi dilakukan atas dasar rida sama rida ('an-tarāḍin) tanpa ada paksaan;

e. Tidak ada unsur riba, maysìr (perjudian), gharar (ketidakjelasan), tadlīs (penipuan), ḍarar (kerusakan/kemudaratan) dan tidak mengandung maksiat.

Dari uraian di atas dapat dipahami bahwa Islam sangat menganjurkan investasi tapi bukan semua bidang usaha diperbolehkan dalam berinvestasi. Aturan-aturan di atas menetapkan batasan-batasan yang halal atau boleh dilakukan dan haram atau tidak boleh dilakukan. Tujuannya adalah untuk mengendalikan manusia dari kegiatan yang membahayakan masyarakat.

Semua transaksi yang terjadi di bursa efek misalnya harus atas dasar suka sama suka, harus jelas dan transparan, informsi antar pihak harus seimbang, tidak ada unsur pemaksaan, tidak ada pihak yang dizalimi atau menzalimi, tidak ada unsur riba, unsur spekulatif atau judi (maysìr), haram jika ada unsur insider trading (Aziz 2010). Inilah beberapa yang perlu dipatuhi para investor agar harta yang diinvestasikan mendapatkan berkah dari Allah, 
bermanfaat bagi orang banyak sehingga mencapai falāh (sejahtera lahirbatin) di dunia juga di akhirat.

Prinsip-prinsip di atas merupakan saripati dari sumber rujukan utama yaitu Al-Qur'an dan Sunnah nabi Muhammad saw., yang kemudian dielaborasi oleh para ulama agar mudah difahami dan diimplementasikan dalam kegiatan ekonomi dan bisnis. Berdiri di atas asas tersebut prinsip syariah yang diatur oleh fatwa Dewan Syariah Nasional Majelis Ulama Indonesia (DSN-MUI) sebagai lembaga yang legal mengeluarkan fatwa terkait aktivitas ekonomi dan bisnis. Fatwa DSN-MUI mengatur berbagai macam transaksi ekonomi, keuangan dan bisnis termasuk di dalamnya kegiatan investasi agar sesuai dengan koridor syariah. Secara khusus fatwa DSN-MUI No. 80/DSNMUI/III/2011 mengatur bagaimana memilih investasi yang dibolehkan syariat dan melarang kegiatan yang bertentangan dengan prinsip syariah dalam kegiatan investasi dan bisnis, yaitu:

a. Maisīr, yaitu setiap kegiatan yang melibatkan perjudian dimana pihak yang memenangkan perjudian akan mengambil taruhannya;

b. Gharar, yaitu ketidakpastian dalam suatu akad, baik mengenai kualitas atau kuantitas objek akad maupun mengenai penyerahannya;

c. Riba, tambahan yang diberikan dalam pertukaran barang-barang ribawi (al-amwāl al-ribawiyyah) dan tambahan yang diberikan atas pokokutang dengan imbalan penangguhan imbalan secara mutlak;

d. Bāțil, yaitu jual beli yang tidak sesuai dengan rukun dan akadnya (ketentuan asal/ pokok dan sifatnya) atau tidak dibenarkan oleh syariat Islam;

e. Bay'i ma'dūm, yaitu melakukan jual beli atas barang yang belum dimiliki;

f. Ihtikār, yaitu membeli barang yang sangat dibutuhkan masyarakat (barang pokok) pada saat harga mahal dan menimbunnya dengan tujuan untuk menjual kembali pada saat harganya lebih mahal; 
Elif Pardiansyah

g. Taghrīr, yaitu upaya mempengaruhi orang lain, baik dengan ucapan maupun tindakan yang mengandung kebohongan, agar terdorong untuk melakukan transaksi;

h. Ghabn, yaitu ketidakseimbangan antara dua barang (objek) yang dipertukarkan dalam suatu akad, baik segi kualitas maupun kuantitas;

i. Talaqqī al-rukbān, yaitu merupakan bagian dari ghabn, jual beli atas barang dengan harga jauh di bawah harga pasar karena pihak penjual tidak mengetahui harga tersebut;

j. Tadlīs, tindakan menyembunyikan kecacatan objek akad yang dilakukan oleh penjual untuk mengelabui pembeli seolah-olah objek akad tersebut tidak cacat;

k. Ghishsh, merupakan bagian dari tadlīs, yaitu penjual menjelaskan atau memaparkan keunggulan atau keistimewaan barang yang dijual serta menyembunyikan kecacatan;

1. Tanājush/Najsh, yaitu tindakan menawar barang dangan harga lebih tinggi oleh pihak yang tidak bermaksud membelinya, untuk menimbulkan kesan banyak pihak yang bermniat memblinya;

m. Dharar, tindakan yang dapat menimbulkan bahaya atau kerugian bagi pihak lain;

n. Rishwah, yaitu suatu pemberian yang bertujuan untuk mengambil sesuatu yang bukan haknya, membenarkan yang bathil dan menjadikan yang bathil sebagai ssesuatu yang benar;

o. Maksiat dan zalim, yaitu perbuatan yang merugikan, mengambil atau menghalangi hak orang lain yang tidak dibenarkan secara syariah, sehingga dapat dianggap sebagai salah satu bentuk penganiayaan

Mengacu pada paparan di atas, dalam aktivitas muamalah selama tidak ditemukan unsur-unsur yang dilarang syariah seperti yang diuraikan di atas, maka kegiatan investasi boleh dilakukan apapun jenisnya. Disamping itu, 
Investasi dalam Perspektif Ekonomi Islam...

dengan aturan seperti itu akan memberikan keleluasaan investor dan pengelola investasi (manager investasi) untuk berkreasi, berinovasi, dan berakselerasi dalam pengembangan produk maupun usahanya. Dasar dari kegiatan ekonomi, bisnis dan investasi adalah kreatifitas yang dibingkai dalam tatanan prinsip syariah. Muara akhir dari kegiatan ekonomi, bisnis dan investasi dengan berlandaskan syariah dimaksudkan untuk mencapai kemuliaan hidup (falāh) yaitu bahagia dunia dan akhirat.

\section{Akad-akad Syariah dalam Investasi}

Akad dalam fikih klasik didefinisikan sebagai pertalian antara ijab dan qabul yang dibenarkan oleh syariat dan memiliki konsekuensi hukum terhadap objeknya (al-Zuhaily 1085). Sedangkan definisi akad dalam tulisan ini adalah perjanjian atau kontrak tertulis antara para pihak yang memuat hak dan kewajiban masing-masing pihak yang tidak bertentangan dengan prinsip syariah. Terdapat banyak pilihan dan skema akad yang menunjang kegiatan ekonomi, bisnis dan investasi baik di sektor riil maupun sektor non-riil, perusahaan privat maupun publik, dan perusahaan swasta maupun perusahaan milik pemerintah, di antaranya adalah:

a. Akad mushārakah atau shirkah (perkongsian), yaitu perjanjian (akad) kerjasama antara dua pihak atau lebih (syarīk) dengan cara menyertakan modal baik dalam bentuk uang maupun bentuk aset lainnya untuk melakukan suatu usaha (Mas'adi 2002);

b. Muḍārabah/qirāḍ, yaitu perjanjian (akad) kerjasama antara pihak pemilik modal (șāhib al-māl) dan pihak pengelola usaha (muḍārib) dengan cara pemilik modal (șạhib al-māl) menyerahkan modal dan pengelola usaha (muḍārib) mengelola modal tersebut dalam suatu usaha (Suhendi 2010);

c. Ijārah (sewa/jasa), yaitu perjanjian (akad) antara pihak pemberi sewa atau pemberi jasa (mu'jir) dan pihak penyewa atau pengguna jasa (musta'jir) untuk memindahkan hak guna (manfaat) atas suatu objek 
ijarah, yang dapat berupa manfaat barang dan/atau jasa dalam waktu tertentu, dengan pembayaran sewa dan/atau upah (ujrah) tanpa diikuti dengan pemindahan kepemilikan objek Ijarah itu sendiri;

d. Kafālah adalah perjanjian (akad) antara pihak penjamin (kafil/guarantor) dan pihak yang dijamin (makfül 'anhu/așill/orang yang berutang) untuk menjamin kewajiban pihak yang dijamin kepada pihak lain (makfül lahu/orang yang berpiutang);

e. Wakālah adalah perjanjian (akad) antara pihak pemberi kuasa (muwakkil) dan pihak penerima kuasa (wakill) dengan cara pihak pemberi kuasa (muwakkil) memberikan kuasa kepada pihak penerima kuasa (wakīl) untuk melakukan tindakan atau perbuatan tertentu.

Tentunya, akad dalam dunia investasi tidak terbatas pada akad yang dipaparkan di atas, namun masih banyak lagi akad yang dapat diimplementasikan pada sektor bisnis dan investasi ini. Terlebih saaat ini, perkembangan zaman sudah begitu cepat khususnya dalam sektor investasi. Munculnya produk-produk baru di dunia bisnis mendorong para pemangku kepentingan untuk berinovasi dan menkreasi desain akad-akad syariah agar sesuai dengan kebutuhan dan kondisi zaman. Akad tunggal seperti yang dipaparkan di atas dirasa tidak mampu lagi menjawab permasalahan dunia bisnis, keuangan dan investasi. Karena itu, dilakukanlah pengembangan dengan mengkombinasikan beberapa akad. Inilah yang kemudian dinamakan multi akad atau hybrid contract (al-uqūd al-murakkabah).

Beberapa akad jenis ini diakomodir dan mendapat legitimasi hukum fatwa DSN MUI, seperti akad mushārakah mutanāqisah (MMQ), akad ijārah muntahiya bi al-tamlīk (IMBT), ijārah maușūfah fi al-dhimmah (IMFZ), akad wakālah bi al-ujrah, murābahah wa al-wakālah, akad kafālah bi al-ujrah, hawālah wa al-wakālah, mudarabah mushtarakah dan masih banyak lagi akad-akad syariah lainnya. Multi akad dikembangkan dan diakui di berbagai negara yang menerapkan sistem keuangan Islam. Hal inilah yang 
membedakan bisnis Islam dengan model keuangan lainnya, dimana inovasi dan kreasi produk sangat diapresiasi. Pada akhirnya perkembangan produk bisnis menjadi banyak, menyerap banyak tenaga kerja, menciptakan banyak lapangan usaha, dan memberikan kemaslahatan bagi perekonomian nasional dengan tetap berpegang pada prinsip-prinsip syariah dalam transaksi, bisnis, dan investasi.

\section{Spekulasi dan Risiko dalam Investasi Syariah}

Unsur spekulasi dalam perilaku investasi konvensional diyakini oleh banyak kalangan dapat memberikan kontribusi bagi berbagai krisis perekonomian dunia. Sebagai contoh, great depression pada tahun 1930-an diawali dengan spekulasi besar-besaran di Wall Street. Selain itu, devaluasi poundsterling pada tahun 1967 dan krisis mata uang frank pada tahun 1969. Terakhir devaluasi bath Thailand menyebabkan penarikan investasi besarbesaran di pasar modal yang kemudian menimbulkan krisis ekonomi. Hal demikian, menurut Esta, membawa kesadaran bagi investor akan pentingnya investasi yang lebih etis (Lestari 2008). Spekulasi dalam hal ini tidak boleh dilakukan karerna menyebabkan kerusakan dan ketidakpastian.

Dalam sistem ekonomi konvensional, seseorang melakukan investasi dengan motif yang berbeda-beda, di antaranya untuk memenuhi kebutuhan likuiditas, menabung dengan tujuan mendapatkan pengembalian yang lebih besar, merencanakan pensiun, untuk berspekulasi, dan lain sebagainya. Begitu pula dalam ekonomi Islam, investasi merupakan kegiatan muamalah yang sangat dianjurkan, karena dengan berinvestasi harta yang dimiliki menjadi produktif dan juga mendatangkan manfaat bagi orang lain. Al-Qur'an dengan tegas melarang aktivitas penimbunan (iḥtikâr) terhadap harta yang dimiliki. Islam memiliki sistem perekonomian yang diselenggarakan dalam rangka mewujudkan kesejahteraan kehidupan manusia baik secara material maupun non material. 
Investasi syariah adalah investasi yang didasarkan pada prinsip-prinsip syariah, baik investasi pada sektor riil maupun sektor keuangan. Sehingga investasi tidak dapat dilepaskan dari prinsip-prinsip syariah. Sehingga tujuan atau niat spekulasi dalam bisnis dan investasi tidak boleh bertentangan dengan syariah. Pada dasarnya, segala aktivitas bisnis memang tidak bisa lepas dari ketidakpastian, yaitu kemungkinan untung atau rugi suatu usaha. Sehingga manusia berspekulasi dalam menentukan pilihan investasi usahanya, terlepas bakal untung atau rugi. Artinya usaha apapun mengandung ketidakpastian untung atau rugi. Ketidakpastian dalam hal ini, lazimnya dikenal dengan istilah gharar.

Secara operasional gharar diartikan sebagai kedua belah pihak tidak memiliki kepastian terhadap barang yang menjadi objek transaksi baik terkait kualitas, kuantitas, harga, dan waktu penyerahaan barang, sehingga ada pihak yang merasa dirugikan haknya. Maqāṣid (tujuan) pelarangan gharar yaitu apabila suatu aktivitas atau kondisi dapat menimbulkan kerugian, perselisihan, dan permusuhan antar para pihak yang terkait. Namun demikian, larangan gharar berlaku dalam jenis transaksi mu'āwaḍah (bisnis), dan tidak berlaku pada transaksi tabarru' (sosial). Namun, gharar yang dimaksud pada bab ini adalah ketidakpastian untung atau rugi dalam bisnis dan investasi.

Dalam perkembanngannya, gharar dibedakan menjadi 2 (dua) kategori, yaitu gharar berat dan gharar ringan (Sahroni 2016). Gharar yang dilarang adalah gharar berat (fähish). Gharar jenis ini diharamkan karena pada dasarnya ketidakjelasannya dapat dihindari dan jika terdapat unsur ini maka akan menimbulkan perselisihan dan permusuhan. Sedangkan gharar ringan/sedikit (qalīl) dibolehkan karena gharar jenis ini tidak dapat dihindarkan atau sangat sulit dihindarkan dari transaksi bisnis. Sehingga keberadaaanya dimaklumi sebagai 'urf al-tujjār (tradisi pebisnis) dan tidak ada pihak yang dirugikan akibat gharar ini. Dalam praktiknya, gharar ringan/sedikit (qalīl) dapat ditemukan dalam transaksi membeli rumah, 
Investasi dalam Perspektif Ekonomi Islam...

tetapi fondasi rumahnya tidak dapat dilihat, jumlah hari dalam bulannya tidak pasti, dan lain sebagainya.

Namun demikian, pada praktiknya di lapangan agak sulit membedakan antara tindakan investasi dengan tindakan spekulasi karena keduanya memiliki tujuan yang sama, yaitu untuk memdapatkan pengembalian lebih terhadap apa yang dikorbankan atau dikeluarkan. Namun, tindakan keduanya dapat dibandingkan seperti yang terlihat pada tabel 2 .

Tabel 1. Perbandingan Tindakan Investasi dan Tindakan Spekulasi

\begin{tabular}{|c|c|c|}
\hline No & Investor & Spekulator \\
\hline 1 & $\begin{array}{r}\text { Rasional dalam mengambil keputusan, } \\
\text { berhati-hati, dan melakukan analisis } \\
\text { yang cermat }\end{array}$ & $\begin{array}{r}\text { Kadang-kadang tidak rasional dalam } \\
\text { menentukan analisis dan terkadang } \\
\text { manipulatif }\end{array}$ \\
\hline 2 & $\begin{array}{r}\text { Mengumpulkan informasi selengkap } \\
\text { mungkin }\end{array}$ & $\begin{array}{r}\text { Memanfaatkan informasi yang } \\
\text { simpang siur dan membuat rumor } \\
\text { yang menguntungkan dirinya }\end{array}$ \\
\hline 3 & $\begin{array}{r}\text { Ekspektasi return dalam jangka } \\
\text { panjang }\end{array}$ & $\begin{array}{r}\text { Ekspektasi return besar dalam waktu } \\
\text { singkat }\end{array}$ \\
\hline 4 & $\begin{array}{r}\text { Pada umumnya risiko yang diambil } \\
\text { bersifat moderat }\end{array}$ & $\begin{array}{r}\text { Memanfaatkan risiko tinggi dalam } \\
\text { berspekulasi }\end{array}$ \\
\hline 5 & $\begin{array}{r}\text { Mengharapkan return sesuai dengan } \\
\text { risiko }\end{array}$ & $\begin{array}{r}\text { Mengharapkan return yang tinggi dan } \\
\text { menolak risiko tinggi }\end{array}$ \\
\hline 6 & $\begin{array}{l}\text { Harga sekuritas sebagai cerminan } \\
\text { informasi kondisi ekonomi sebenarnya }\end{array}$ & $\begin{array}{r}\text { Tidak peduli kondisi ekonomi, baik } \\
\text { mikro maupun makro, dan cenderung } \\
\text { menyukai kondisi ekonomi yang } \\
\text { bergejolak untuk berspekulasi }\end{array}$ \\
\hline 7 & $\begin{array}{r}\text { Berdampak pada pasar yang } \\
\text { bergejolak namun pasti (fluktuasi yang } \\
\text { wajar) }\end{array}$ & $\begin{array}{l}\text { Berdampak pada pasar yang } \\
\text { bergejolak dengan fluktuasi tinggi }\end{array}$ \\
\hline
\end{tabular}

Sumber: Nurlita, 2015: 16

Perilaku spekulasi dari para investor sulit dibedakan karena pada ujungnya berbeda pada levet niat. Sejauh mana niat investor memberikan

Economica: Jurnal Ekonomi Islam - Volume 8, Nomor 2 (2017) 
dananya untuk dikelola dalam bentuk entitas usaha tertentu. Namun yang tidak kalah penting adalah pembahasan tentang risiko investasi dalam Islam. Semua bentuk investasi mengandung risiko atau ketidakpastian hasil. Menurut Husnan (Husnan 1996) risiko adalah kemungkinan hasil yang menyimpang dari harapan. Besarnya keuntungan yang diharapkan dari setiap sekuritas tidaklah sama, bergantung pada besarnya risiko yang ditanggung investor. Namun, yang dapat dilakukan investor adalah meminimalkan risiko dengan memperhatikan besarnya pengaruh masing-masing faktor tersebut. Dalam teori portofolio, risiko adalah tingkat penyimpangan terhadap keuntungan yang diharapkan. Risiko dalam investasi timbul karena adanya ketidakpastian waktu dan besarnya return yang akan diterima investor Menurut Zubir (Zubir 2011), faktor-faktor penyebab timbulnya risiko akan memengaruhi melencengnya realisasi return suatu investasi terhadap nilai yang diharapkan (expected return). Sumber risiko di antaranya adalah sebagai berikut:

a. Interest rate risk, yaitu risiko yang disebabkan oleh perubahan tingkat bunga tabungan dan tingkat bunga pinjaman, namun di dalam pandangan Islam variabel ini tidak berlaku, karena Islam melarang bunga;

b. Market risk, yaitu risiko yang disebabkan oleh gejolak (variability) return suatu investasi sebagai akibat dari fluktuasi transaksi di pasar secara keseluruhan;

c. Inflation risk, yaitu risiko yang disebabkan oleh menurunnya daya beli masyarakat sebagai akibat dari kenaikan harga barang-barang secara umum;

d. Business risk, yaitu risiko yang disebabkan oleh tantangan bisnis yang dihadapi perusahaan makin berat, baik akibat tingkat persaingan yang makin ketat, perubahan peraturan pemerintah, maupun klaim dari masyarakat terhadap perusahaan karena merusak lingkungan; 
Investasi dalam Perspektif Ekonomi Islam...

e. Financial risk, yaitu risiko keuangan yang berkaitan dengan struktur modal yang digunakan untuk mendanai kegiatan perusahaan;

f. Liquidity risk, yaitu risiko yang berkaitan dengan kesulitan untuk mencairkan portofolio atau menjual saham karena tidak ada yang membeli saham tersebut;

g. Exchange rate risk atau currency risk, yaitu risiko bagi investor yang melakukan investasi di berbagai negara dengan berbagai mata uang, perubahan nilai tukar mata uang akan menjadi faktor penyebab riil return lebih kecil daripada expected return;

h. Country risk, yaitu risiko ini juga berkaitan dengan investasi lintas negara yang disebabkan oleh kondisi politik, keamanan, dan stabilitas perekonomian tersebut. Makin tidak stabil keamanan, politik, dan perekonomian suatu negara, makin tinggi risiko berinvestasi di negara tersebut karena return investasi jadi makin tidak pasti, sehingga kompensasi atau return yang dituntut atas suatu investasi makin tinggi.

Jenis-jenis risiko tersebut umumnya terdapat dalam investasi pada lembaga keuangan atau sektor keuangan, namun tidak menutup kemungkinan juga terdapat pada sektor bisnis non-keuangan. Kedelapan jenis risiko tersebut tidak semuanya diakui dalam investasi Islam. Karena bunga (interest) bukan bagian dari sistem keuangan Islam. Namun demikian, screening syariah saat ini di beberapa negara memberikan ruang bagi perusahaan yang memiliki utang berbasis bunga dengan batas maksimal $45 \%$ terhadap total aset. Hal demikian dibolehkan dengan alasan saat ini, perusahaan belum mampu keluar sepenuhnya dari bayang-bayang bank konvensional. Di sisi lain bank syariah belum mampu mengakomodir kebutuhan perusahaan dalam hal pembiayaan penambahan modal.

Islam memandang risiko sebagai suatu sunatullah (hukum alam). Hal demikian, terdapat kaidah yang dalam fikih muamalah, al-kharaj bi al-damān dan kaidah al-ghunmu bi al-ghurmi yang artinya "keuntungan akan 
berbanding lurus dengan tanggung jawab terhadap risiko/kerugian". Dalam bahasa populernya, kaidah ini kurang lebih sama dengan high risk high return. Artinya dalam pandangan Islam, modal yang kita tanamkan untuk investasi akan menghadapi beberapa kemungkinan; bisa untung, impas, atau rugi. Dalam akad shirkah atau mushārakah, kerugian dibagi berdasarkan proporsi modal masing-masing, bahkan kerugian bisa ditanggung penuh investor dalam investasi akad muḍ̄arabah dengan catatan kerugian dan risiko terjadi akibat alamiah bisnis bukan karena perilaku curang atau lalai dari pengelola (fraud). Syariat Islam telah menjadikan kedua hal tersebut menjadi dua hal yang selalu beriringan, bahwa kharaj/ribh/ghunm tidak bisa didapatkan kecuali dengan ḍamān/mukhātarah/ghurm (Sahroni 2016).

\section{Memilih Investasi Islami dengan Metode Screening Syariah}

Dalam pandangan Islam investasi adalah bagian integral dari kegiatan bisnis. Dalam konteks maqāṣid syariah, kegiatan bisnis adalah bentuk lain dari cara mencari rezeki. Oleh sebab itu, hal demikian menjadi wajib sebagai sarana menyediakan kebutuhan harta dari aspek wujud, karena tanpa bekerja tidak mungkin ada uang dan harta (Sahroni 2016). Dari sisi ekonomi, harta yang tidak diinvestasikan dimungkinkan akan menjadi harta yang tidak berguna dan tidak memiliki nilai manfaat lebih. Ajaran Islam tidak menyukai adanya tindakan menimbun harta. Dalam berinvestasi umat Islam tidak boleh asal menempatkan modalnya. Dilihat dulu profil perusahaan, transaksi yang dilakukan, barang/obyek yang ditransaksikan, semuanya harus mengikuti prinsip-prinsip Islam dalam bermuamalah (Sakinah 2015). Di satu sisi, Islam memberikan disinsentif terhadap saving yang tidak diinvestasikan, namun di sisi lain Islam memberikan insentif untuk melakukan investasi. Konsekuensi logis dari investasi adalah munculnya kemungkinan untung dan rugi. Syariat Islam telah memberikan kedua hal tersebut menjadi yang beriringan. Kaidahnya adalah al-kharaj bi al-damān, maksudnya al-kharaj tidak bisa didapatkan tanpa adanya al-ḍamān. Al-kharaj maknanya adalah keuntungan, 
Investasi dalam Perspektif Ekonomi Islam...

sedangkan al-ḍamān adalah tanggung jawab atas risiko, kerugian atau kerusakan usaha.

Demikianlah, mengapa Islam melarang membiarkan aset menganggur (idle) dan mendorong setiap kekayaan yang dimiliki dialokasikan sebagian untuk investasi di sektor riil maupun sektor non-riil. Kedua sektor investasi tersebut diakui karena keberadaannya diyakini sangat penting bagi roda perekonomian nasional. Sektor riil diwakili oleh Usaha Kecil dan Menengah (UKM) dan Usaha Mikro Kecil dan Menengah (UMKM), dan perusahaanperusahaan yang belum atau tidak melakukan go public. Sedangkan yang dimaksud sektor non-riil dalam hal ini bukan berarti keberadaaan usaha dan aktifitasnya tidak ada, namun dilakukan di pasar khusus yang dinamakan pasar modal syariah. Investasi dalam hal ini adalah ikut menyertakan modal dengan cara membeli saham sebagai bukti kepemilikan perusahaan.

Saham merupakan bagian dari investasi dalam Islam. Secara konsep, saham merupakan surat berharga bukti penyertaan modal kepada perusahaan dan dengan bukti penyertaan tersebut pemegang saham berhak untuk mendapatkan bagian hasil dari usaha perusahaan tersebut. Konsep penyertaan modal dengan hak bagian hasil usaha ini merupakan konsep yang tidak bertentangan dengan prinsip syariah. Prinsip syariah mengenal konsep ini sebagai kegiatan mushārakah atau shirkah. Berdasarkan analogi tersebut, maka secara konsep saham merupakan efek yang tidak bertentangan dengan prinsip syariah. Namun demikian, tidak semua saham yang diterbitkan oleh emiten dan perusahaan publik dapat disebut sebagai saham syariah.

Secara umum, dalam mengidentifikasi kategori saham syariah, setidaknya harus melalui 2 (dua) proses, yaitu proses penyaringan (screening) dan proses pembersihan (cleansing) dengan ketentuan sebagai berikut:

a. Emiten dan perusahaan publik yang secara jelas menyatakan dalam anggaran dasarnya bahwa kegiatan usaha emiten dan perusahaan publik tidak bertentangan dengan prinsip-prinsip syariah; 
b. Emiten dan perusahaan publik yang tidak menyatakan dalam anggaran dasarnya bahwa kegiatan usaha emiten dan perusahaan publik tidak bertentangan dengan prinsip-prinsip syariah, namun memenuhi kriteria sebagai berikut:

1) Kriteria kegiatan usaha

Perusahaan tidak boleh melakukan kegiatan usaha bertentangan dengan prinsip syariah sebagaimana diatur dalam Peraturan Otoritas Jasa Keuangan No. 15/POJK.04/2015 dan fatwa DSN-MUI No. 80/DSN-MUI/III/2011. Kegiatan usaha yang dilarang tersebut adalah:

a. perjudian dan permainan yang tergolong judi;

b. perdagangan yang tidak disertai dengan penyerahan barang/jasa;

c. perdagangan dengan penawaran/permintaan palsu;

d. bank berbasis bunga;

e. perusahaan pembiayaan berbasis bunga;

f. jual beli risiko yang mengandung unsur ketidakpastian (gharar) dan/atau judi (maysirr), antara lain asuransi konvensional;

g. memproduksi, mendistribusikan, memperdagangkan dan/atau menyediakan barang atau jasa haram zatnya (harām li dhātihi), barang atau jasa haram bukan karena zatnya (harām li ghairihi) yang ditetapkan oleh DSN-MUI; dan/atau, barang atau jasa yang merusak moral dan bersifat mudarat;

h. melakukan transaksi yang mengandung unsur suap (rishwah);

2) Kriteria rasio keuangan 
Investasi dalam Perspektif Ekonomi Islam...

a. Rasio antara total utang berbasis bunga dibandingkan dengan total aset tidak lebih dari 45\% (empat puluh lima persen); dan

b. Rasio total pendapatan bunga dan total pendapatan tidak halal lainnya dibandingkan total pendapatan usaha (revenue) dan total pendapatan lainnya tidak lebih dari 10\% (sepuluh persen)

Gambar 2. Proses screening saham syariah

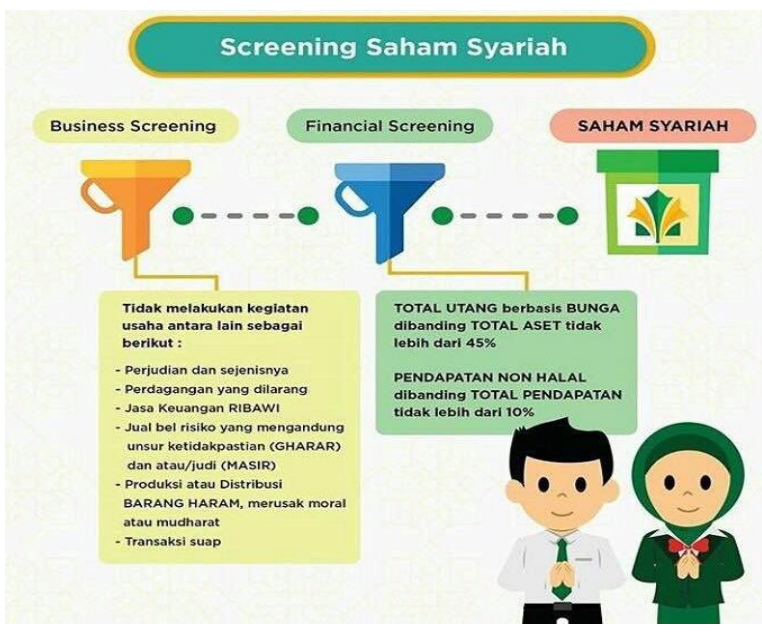

Sumber: Materi TOT Pasar Modal Syariah OJK, 2017

Selain core of business-nya harus yang sesuai syariah, metodologi screening syariah di Indonesia sangat detail mengatur bagaimana porsi $45 \%$ rasio utang berbasis bunga terhadap seluruh aset perusahaan mengindikasikan gairah secara perlahan lepas dari bayang-bayang sistem ribawi. Begitupun dengan pemisahan pendapatan halal dengan pendapatan non-halal dengan rasio 10\%. Hal ini sesuai kaidah memisahkan yang halal dari yang haram (tafrīq al-halāl 'an al-harām) yang dijadikan salah satu bagian dari metode ijtihad DSN-MUI. Penjelasannya, bahwa harta atau uang dalam perspektif fikih bukanlah benda haram karena zatnya ('ainiyah) tapi haram karena cara memperolehnya yang tidak sesuai syariah (lighairihi), sehingga dapat untuk dipisahkan mana yang diperoleh dengan cara halal dan mana

Economica: Jurnal Ekonomi Islam - Volume 8, Nomor 2 (2017) 
Elif Pardiansyah

yang non-halal. Dana yang halal dapat diakui sebagai penghasilan sah, sedangkan dana non-halal harus dipisahkan dan dialokasikan untuk kepentingan umum (Amin 2017).

Proses screening di atas tidak hanya ada di Indonesia, namun juga di negara-negara lain sperti Malaysia, Hongkong, Singapura, dan Amerika, yaitu dengan metodologi yang sama, berbasis aktivitas bisnis dan rasio keuangan berbasis non-halal. Oleh sebab itu, screening syariah ini dapat diadopsi dalam memilih investasi perusahaan yang sesuai dengan prinsip syariah. Proses demikian untuk menghindari perusahaan yang melakukan aktifitas bisnisnya menyimpang dari ketentuan syariat Islam, yang sangat menjaga hak seseorang atas harta investasinya (hifz al-māl). Praktik-praktik bisnis dengan dalih investasi dewasa ini banyak yang teridentifikasi "bodong” oleh OJK.

Jenis investasi yang ada di Indonesia sangat beragam modelnya. Terdapat yang memenuhi prinsip dasar syariah, namun ada juga yang tidak memenuhi ketentuan syariah. Investasi dapat dikatakan memenuhi syariah Islam yaitu dengan mengakomodir beberapa prinsip yang sudah dijelaskan di atas. Paparan di atas setidaknya menjelaskan 3 (tiga) prinsip yaitu tentang kehalalannya, keberkahannya, dan pertambahannya yang mencakup risiko dan keuntungan (Chair 2015). Artinya investasi itu apapun jenis kegiatannya harus mengacu pada prinsip dasar ini agar tidak terjerumus pada investasi yang merugikan. Dewasa ini, telah banyak jenis investasi yang menawarkan produknya dengan membabi-buta. Tanpa memperhatikan etika investasi, prinsip syariah dan aturan main yang diatur oleh OJK.

Satgas Waspada Investasi OJK pada pertengahan Desember 2017 merilis 21 daftar entitas perusahaan investasi yang harus diwaspadai masyarakat. Entitas perusahaan tersebut diduga melakukan praktik bisnis yang mencurigakan. Dugaan tim Satgas Waspada Investasi OJK didasarkan pada 2 (dua) alasan utama, yaitu: (1) tidak memiliki izin usaha penawaran produk dan penawaran investasi sehingga berpotensi merugikan masyarakat; dan (2) imbal hasil atau keuntungan yang dijanjikan tidak masuk akal. 
Investasi dalam Perspektif Ekonomi Islam...

Tabel 2. Entitas investasi yang harus diwaspadai menurut OJK

\begin{tabular}{crr}
\hline No & Entitas & Kegiatan Usaha \\
\hline 1 & PT. Ayudee Global Nusantara & Digital marketing produk kecantikan \\
Ayudee
\end{tabular}

Sumber: Satgas Waspada Investasi OJK, 2017

Masih banyaknya entitas yang menawarkan investasi dengan return yang snagat tinggi dan tidak masuk akal adalah salah satu poin penting

Economica: Jurnal Ekonomi Islam - Volume 8, Nomor 2 (2017) http://journal.walisongo.ac.id/index.php/economica 
penilaian tim Satgas Waspada Investasi OJK. Hal ini untuk meminimalisir entitas perusahaan yang memanfaatkan kesempatan menghimpun dana sebanyak mungkin namun tidak dapat dikembalikan. Modus yang dilakukan entitas perusahaan di atas bermacam-macam. Contoh kasus, seperti yang dilakukan PT. RWI, dimana kegiatannya berupa kegiatan pendistribusian atau penjualan produk sabun wajah atau facial soap dengan label blackwalet. Modusnya adalah menawarkan program rekrutmen member dengan biaya pendaftaran sebesar Rp. 100.000,-. Adapun keuntungan yang ditawarkan adalah:

1) Bonus Harian

a. Bonus referral, dimana setiap berhasil mereferensikan satu orang maka akan diberikan bonus sebesar Rp. 20.000,-.

b. Bonus pasangan, setiap terjadi keseimbangan kanan dan kiri maka akan diberikan bonus sebesar Rp. 20.000,- dengan batas flush out 50 (lima puluh) pasang per hari. Potensi bonus pasangan adalah Rp. 1.000.000,- per hari.

2) Bonus Bulanan

Bonus yang diperoleh dari perhitungan bonus harian pribadi dan bonus harian member jalur sponsoring. Selain itu juga, terdapat poin reward yang diberikan yaitu :

a. $\quad 10.000$ (sepuluh ribu) poin mendapat Asia Tour;

b. 50.000 (lima puluh ribu) poin mendapat Star Cruise Tour;

c. 150.000 (seratus lima puluh ribu) poin mendapat Europe Tour.

3) Bonus Triwulan

Bonus yang terakumulasi sebesar Rp. 1.000.000,- maka secara otomatis sistem akan memasukan dalam program Dana Pensiun dengan syarat akan dikenakan biaya sebesar Rp100.000,- (hanya sekali) yang diambil dari saldo bonus. Berikut tabel potensi Dana Pensiun: 
Investasi dalam Perspektif Ekonomi Islam...

Tabel 3. Potensi Dana Pensiun PT. PWI

\begin{tabular}{rrrr}
\hline Gen & Rupiah & Member & Total Dana Pensiun (Rp) \\
\hline 1 & 10.000 & 4 & 40.000 \\
2 & 10.000 & 16 & 200.000 \\
3 & 10.000 & 64 & 840.000 \\
4 & 10.000 & 256 & 3.400 .000 \\
5 & 10.000 & 1.024 & 13.640 .000 \\
6 & 10.000 & 4.096 & 54.600 .000 \\
7 & 10.000 & 16.384 & 218.440 .000 \\
8 & 10.000 & 65.536 & 873.800 .000 \\
9 & 10.000 & 262.144 & 3.495 .240 .000 \\
\hline
\end{tabular}

Sumber: Lampiran satgas waspada investasi OJK, 2017

4) Reward, diberikan ketika mencapai peringkat "Star Leader", yaitu ketika sudah mensponsori 10 (sepuluh) paket Kanan dan Kiri. Berikut daftar reward yang dimaksud :

a. $10: 10$ mendapatkan handphone senilai Rp. 1.000.000,-.

b. $50: 50$ mendapatkan reward Tab senilai Rp. 5.000.000,-.

c. 500 : 500 mendapatkan reward motor Vario senilai Rp. 17.500.000,-

d. $1.500: 1.500$ mendapatkan reward umrah senilai Rp. 45.000.000,-.

e. 3.500 : 3.500 mendapatkan reward mobil Agya senilai Rp. 115.000.000,-

f. $\quad 9.500$ : 9.500 mendapatkan reward mobil Fortuner senilai Rp. $450.000 .000,-\cdot$

g. 25.000: 25.000 mendapatkan reward Rumah senilai Rp. 1 milyar.

Menarik bila melihat deretan angka reward dan return yang ditawarkan PT. PWI di atas. Sekilas tidak ada yang aneh dari model bisnis ini, namun bila kita cermati bagaimana pola return dan reward serta produk apa yang dijual, tentu ada beberapa catatan dan kejanggalan dengan menggunakan 
Elif Pardiansyah

pendekatan screening syariah, dengan dua indikator yang dipakai, yaitu core of business dan finantial ratio.

Untuk melihat model bisnis PT. PWI apakah sesuai atau tidak dengan prinsip syariah, setidaknya harus dilihat dari 3 (tiga) sisi. Pertama, deklarasi perusahaan di dalam AD/ART yang menyatakan bahwa perusahaan tidak bertentangan dengan prinsip syariah. Kedua, produk yang dijual PT. PWI ini apakah bertentangan dengan prinsip syariah dalam bermuamalah atau tidak. Ketiga, dilihat dari proses bisnisnya, bagaimana proses bisnis PT. PWI berjalan dari hulu sampai hilir, sampai penjualan apakah ada prinsip syariah seperti yang dijelaskan di atas yang dilanggar atau tidak.

Secara Anggaran Dasar dan Anggaran Rumah Tangga (AD/ART) perusahaan ini tidak secara tegas menyatakan perusahaan yang berprinsip syariah, sehingga indikator pertama gugur. Bila dilihat dari produk yang dijual, menurut keterangan Satgas Waspada Investasi OJK di atas, kegiatan PT. PWI adalah pendistribusian atau penjualan produk sabun wajah atau facial soap dengan label blackwalet. Berarti produk yang dotawarkan adalah sabun wajah. Pada umumnya sabun adalah produk yang halal dijual-belikan selama tidak mengandung unsur yang diharamkan, najis, dan zat-zat yang membahayakan bagi kesehatan manusia. Memang produk yang ditawarkan belum bersertifikat halal menurut lembaga sertifikasi halal BPOM-MUI. Namun bukan berarti semua yang belum bersertifikat halal menjadi haram. Harus dilakukan pengujian dan penelusuran yang mendalam apakah produk yang dijual-belikan adalah produk yang berbahaya, mengandung zat nonhalal, dan sebagainya.

Yang menarik, bila dilihat dari kacamata proses bisnis, PT. PWI sebagaimana dipaparkan di atas, menjanjikan berbagai bonus/reward dan return yang sangat tinggi. Return yang didapatkan tidak hanya dari hasil penjualan, tetapi dari rekrutmen anggota baru (down-line). Bahkan bonus yang ditawarkan bisa didapatkan harian, bulanan dan triwulanan. Bonus didapat bukan dari hasil langsung penjualan, tetapi dari rekrutmen anggota 
baru. Model bisnis seperti ini sama dengan multi evel marketing (MLM) atau penjualan langsung berjenjang (PLB). Masyarakat yang akan berinvestasi hendaknya memperhatikan fatwa tentang prinsip syariah dalam berinvestasi agar terhindar dari praktek bisnis yang merugikan. Fatwa yang secara rinci mengatur model bisnis seperti PT PWI diatas adalah fatwa DSN-MUI No. 75/DSN-MUI/VII/2009 tentang Penjualan Langsung Berjenjang Syariah. Prinsip syariah yang terdapat dalam fatwa ini kurang lebih sama dengan prinsip syariah fatwa No. 80/DSN-MUI/III/2011.

PT. PWI menjual produk riil berupa barang yaitu sabun muka. Namun demikian, komisi atau reward yang diberikan oleh perusahaan kepada anggota baik besaran maupun bentuknya tidak berdasarkan pada prestasi kerja nyata yang terkait langsung dengan volume atau nilai hasil penjualan barang atau produk jasa. Selain itu, penjualan produk tidak menjadi pendapatan utama mitra usaha PT. PWI. Hal ini bertentangan dengan prinsip syariah dalam fatwa No. 75 dan fatwa No. 80 di atas.

Bonus yang diberikan oleh perusahaan kepada anggota (mitra usaha) jumlahnya jelas sesuai dengan tabel 3. di atas, namun transaksi (akad) tidak terkait dengan volume target penjualan barang dan atau produk jasa yang ditetapkan oleh perusahaan, melainkan sejauhmana dapat merekrut anggota kanan dan kirinya. Komisi atau bonus secara pasif yang diperoleh secara reguler tanpa melakukan pembinaan dan atau penjualan barang dan atau jasa. Pemberian komisi atau bonus oleh perusahaan kepada anggota (mitra usaha) akan menimbulkan ighra'. Ighra' adalah daya tarik luar biasa yang menyebabkan orang lalai terhadap kewajibannya demi melakukan hal-hal atau transaksi dalam rangka memperoleh bonus atau komisi yang dijanjikan. Selanjutnya, dimungkinkan ada eksploitasi dan ketidakadilan dalam pembagian bonus antara anggota pertama dengan anggota berikutnya.

\section{Simpulan}


Elif Pardiansyah

Berdasarkan paparan di atas, dapat dipahami bahwa investasi merupakan komitmen atas sejumlah dana atau sumber daya lainnya yang dilakukan dengan tujuan memperoleh sejumlah keuntungan dan kemaslahatan di masa yang akan datang. Investasi merupakan kegiatan yang sangat dianjurkan dalam Islam bahkan benih dasarnya sudah ada di dalam $\mathrm{Al}$ Qur'an (QS. al-Baqarah [2]: 261; QS. al-Nisa [4]: 9; QS. Yusuf [12]: 46-49; QS. Luqman [31]: 34 dan QS. al-Hasyr [59]: 18) dan diperkuat oleh sunnah nabi Muhammad saw. yang pernah menjadi mitra investor sekaligus pelaku bisnis.

Dasar prinsip investasi syariah adalah semua bentuk investasi pada dasarnya adalah boleh dilakukan sampai ada dalil yang melarangnya, yaitu apabila ditemukan kegiatan terlarang dalam suatu kegiatan bisnis, baik objek maupun caranya (prosesnya), yaitu kegiatan yang mengandung gharar, maysīr, riba, tadlīs, talaqqī rukbān, taghrīr, ghabn, ḍarar, risywah, maksiat dan zalim. Untuk melihat suatu entitas menjalankan kegiatan usahanya berasarkan prinsip syariah atau tidak dapat dilihat dengan metode screening syariah yaitu, pertama melihat bisnis yang dijalankannya, baik itu proses, maupun produk barangnya; kedua, menganalisa rasio pendapatan non-halal dan rasio utang berbasis bunga terhadap jumlah aset yang dimiliki.

Akad yang bisa diimplementasikan di dalam dunia investasi adalah: pertama, akad pokok seperti shirkah/mushārakah yaitu akad persekutuan atau penyertaan modal; kedua, akad mudāarabah yaitu perjanjian penanaman modal usaha tertentu; ketiga, akad ijārah yaitu perjanjian sewa menyewa atau jasa; keempat, akad wakālah yaitu perjanjian perwakilan atau mewakilkan suatu kegiatan; dan kelima, akad kafālah yaitu perjanjian untuk menjamin risiko yang timbul dari kegiatan investasi. Namun demikian tidak menutup kemungkinan akad-akad utama di atas dimodifikasi dan disesuaikan dengan kondisi zaman dan model bisnis, namun tetap tidak boleh bertentangan dengan sumber utama/primer yaitu Al-Qur'an dan hadis. Inovasi pengembangan produk investasi dengan mengembangkan skema akad sangat dibutuhkan para pelaku bisnis agar kegiatan investasi dan bisnis yang 
dijalankan tetap pada koridor syariat Islam. Akad-akad kontemporer seperti MMQ, IMBT, IMFZ, dan kombinasi akad lainnya adalah bagian dari evolusi akad syariah guna sesuai dengan kebutuhan manusia.

Spekulasi adalah bagian dari bisnis dan investasi, namun spekulasi yang dapat merugikan diri dan orang lain serta dapat menimbulkan permusuhan dan perselisihan adalah mutlak dilarang syariat Islam dan bertentangan dengan prinsip syariah. Sedangkan risiko yang timbul dari aktivitas bisnis dan investasi adalah bagian yang tidak terpisahkan dari aktivitas bisnis dan investasi itu sendiri berlaku kaidah al-ghunmu bi al-ghurmi dan al-kharaj bi aldamān (high risk high return) sebagai konsekuensi logis dari aktivitas bisnis dan investasi.

\section{Daftar Pustaka}

Afzalurrahman. 2000. Muhammad as a Trader (Muhammad Sebagai Seorang Pedagang). Jakarta: Yayasan Swarna Bhumi.

al-Zuhaily, Wahbah. 1085. Al-Fiqh Al-Islāmy Wa Adillatuh. Juz 4. Beirūt: Dār alFikr.

Amin, Ma'ruf. 2017. "Solusi Hukum Islam (Makharij Fiqhiyyah) Sebagai Pendorong Arus Baru Ekonomi Syariah Di Indonesia." Orasi Ilmiah Disampaikan Dalam Pengukuhan Guru Besar Bidang Ilmu Ekonomi Muamalat Syariah. Malang.

Antonio, Muhammad Syafi'i. 2007. Muhammad SAW: The Super Leader Super Manager. Jakarta: ProLM Centre \& Tazkia Multimedia.

Arifin, Zainul. 2009. Dasar-Dasar Manajemen Bank Syariah. Tangerang: Azkia Publisher.

Aziz, Abdul. 2010. Manajemen Investasi Syariah. Bandung: Alfabeta.

Basyir, Ahmad Azhar. 2000. Asas-Asas Hukum Muamalat: Hukum Perdata Islam. Yogyakarta: UII Press.

Chair, Wasilul. 2015. "Manajemen Investasi Di Bank Syariah." Iqtishadia: Jurnal Ekonomi \& Perbankan Syariah 2 (2): 203. https://doi.org/10.19105/ iqtishadia.v2i2.848. 
Elif Pardiansyah

Djazuli. A. 2006. Kaidah-Kaidah Fikih: Kaidah Hukum Islam Dalam Menyelesaikan Masalah-Masalah Yang Praktis. Jakarta: Kencana.

Hidayat, Taufik. 2011. Buku Pintar Investasi Syariah. Jakarta: Mediakita.

Husnan, Suad. 1996. Dasar-Dasar Teori Portofolio Dan Analisis Sekuritas. Cetakan Ke. Yogyakarta: UPPAMPYKP.

Kasmir dan Jakfar. 2015. Studi Kelayakan Bisnis. Edisi Revi. Jakarta: Kencana Prenada Media.

Langgulung, Hasan. 1992. Asas-Asas Pendidikan Islam. Jakarta: Pustaka alHusna.

Maharani, Dewi. 2016. "Analisis Pengaruh Investasi Dan Tenaga Kerja Terhadap Produk Domestik Regional Bruto (PDRB) Di Sumatera Utara." Intiqad: Jurnal Agama Dan Pendidikan Islam 8 (2). http://jurnal.umsu.ac.id/index.php/intiqad/article/view/725.

Mas'adi, Ghufron. A. 2002. Fiqh Muamalah Kontekstual. Jakarta: RajaGrafindo Persada.

Nopirin. 2000. Ekonomi Moneter: Buku 1 Edisi Keempat. Yogyakarta: BPFE.

Praja, Juhaya S. 2004. Filsafat Hukum Islam. Tasikmalaya: Latifah Press.

Rahmawan, Ivan. 2005. Kamus Istilah Akuntansi Syariah. Cet. I. Yogyakarta: Pilar Media.

Sahroni, Oni dan Adiwarman A. Karim. 2016. Maqhashid Bisnis \& Keuangan Islam: Sintesis Fikih Dan Ekonomi. Jakarta: Rajawali Press.

Sakinah. 2015. "Investasi Dalam Islam." Iqtishadia: Jurnal Ekonomi \& Perbankan Syariah 1 (2): 248. https://doi.org/10.19105/ iqtishadia.v1i2.483.

Sitompul, Novita Linda. 2007. “Analisis Pengaruh Investasi Dan Tenaga Kerja Terhadap PDRB Sumatera Utara." Universitas Sumatra Utara.

Suhendi, Hendi. 2010. Fiqh Muamalah. Jakarta: RajaGrafindo Persada.

Sukirno, Sadono. 2003. Pengantar Teori Makro Ekonomi. Jakarta: Rajagrafindo Persada.

UII, Pusat Pengkajian dan Pengembangan Ekonomi Islam (P3EI). 2013. Ekonomi Islam. Cet. ke-5. Jakarta: RajaGrafindo Persada.

Yuliana, Indah. 2010. Investasi Produk Keuangan Syariah. Malang: UIN Maliki Press. 
Investasi dalam Perspektif Ekonomi Islam...

Zubir, Zalmi. 2011. Manajemen Portofolio Penerapannya Dalam Investasi Saham. Jakarta: Salemba Empat. 
